\title{
PANDEMIA Y VIOLENCIA POLÍTICA EN ALLÁ AFUERA HAY MONSTRUOS, DE EDMUNDO PAZ SOLDÁN
}

\author{
José Manuel Camacho Delgado \\ Universidad de Sevilla \\ jcamacho@us.es
}

https://orcid.org/0000-0001-6655-7272

Para Manuel González (More), lector de corazón abierto, in memoriam
Para Blanca Estela Treviño, Amiga y Maestra entrañable, in memoriam

RESUMEN: Tras la publicación de Los días de la peste (2017), novela premonitoria que anticipa la pandemia global del COVID-19, el escritor Edmundo Paz Soldán vuelve a sacar una obra sobre los horrores derivados de la propagación del virus (al que llaman el «bicho»), titulada Allá afuera hay monstruos (2021). Ambientada en un mundo distópico y guerracivilista, Paz Soldán recrea con mano maestra cada una de las circunstancias que se han vivido de forma global: el contagio imparable del virus, la falta de equipamiento sanitario, las tensiones económicas derivadas del confinamiento, las revueltas sociales, la contaminación informativa, el protagonismo de los negacionistas y antivacunas o los pseudocientíficos mesiánicos con remedios milagrosos para combatir la pandemia. La obra está inspirada y es un homenaje a Cartucho (1931), libro de relatos sobre la Revolución mexicana de la escritora Nellie Campobello.

PAlabras Clave: Covid-19, pandemia, Los días de la peste, literatura pestífera, Edmundo Paz Soldán, Allá afuera hay monstruos, Nellie Campobello, Cartucho.

\section{PANDEMIC AND POLITIC VIOLENCE IN ALLÁ AFUERA HAY MONSTRUOS BY EDMUNDO PAZ SOLDÁN}

ABSTRACT: After the publication of Los dias de la peste (2017) a premonitory novel that anticipated the global pandemic of covid 19, the writer Edmundo Paz Soldán brings a new work about the horrors that derivated from the virus propagation (that is called «bug») titled Allá afuera hay monstruos (2021). Placed in an civic war distopic world, Paz Soldán recreates with master hand the lack of sanitary equipment, the economic tensions derivated from the lockdown, the social revolts, the informative contamination, the leadership of the anti vaccine movements and the messianic pseudo scientists with miraculous remedies to battle the pandemic. The work is inspired and it is a tribute to Cartucho (1931), a book of short stories about the Mexican revolution by the writer Nelli Campobello.

KEYWORDS: Covid 19, Los dias de la peste, pestiferous literature, Edmundo Paz Soldán, Allá afuera hay monstruos, Nelli Campobello, Cartucho. 
Los temores que atormentan a nuestro linaje humanal paresçen en tres maneras: themor de enfermetat, themor de pobreza, temor de lo que nos viene de mayor poder quel nuestro (Alfonso Chirino, Espejo de medicina, 1414).

\section{LOS HOMENAJES DE UNA NOVELA}

En no pocas ocasiones la realidad le da la razón a la Literatura, funcionando esta como un artefacto premonitorio de las oscuridades abisales que esperan al hombre. Eso fue lo que pasó en 2017 con la publicación de Los días de la peste, ${ }^{1}$ del escritor boliviano Edmundo Paz Soldán, quien sitúa la acción de su novela en un espacio extraño e inquietante, con una fuerte pulsión distópica. Se trata de una «ciudad-cárcel», con fuertes resonancias medievales, en donde se combinan a la perfección elementos futuristas con otros que remiten a épocas pasadas, un espacio carcelario que alberga entre sus muros lo más sórdido y abyecto de la sociedad, con sus ristras inigualables de asesinos en serie, narcotraficantes, violadores, pervertidos sexuales, estafadores, ladrones al por mayor, policías sin escrúpulos, funcionarios corruptos o criminales de toda laya y condición que cohabitan un espacio laberíntico y sorprendente en donde hay diferentes patios que albergan formas miserables de vida con otras que son altamente sofisticadas, lo que permite ver en este espacio cifrado el tránsito desde la más oscura edad pasada a un mundo distópico y futurista (Montoya, 2019). Es en los patios de esta cárcel-gueto, la Casona, como así se llama al recinto penitenciario -inspirada en la prisión de San Pedro, en la Paz (Bolivia)-, donde encontramos la relación permanente entre los presos y todo tipo de insectos, parásitos, roedores, murciélagos y mil alimañas habituales del ecosistema carcelario. Es precisamente en el tercer patio de la cárcel, el lugar en el que encontramos a los criminales más sanguinarios, donde mayor es la presencia de todo tipo de ratas, arañas venenosas, escorpiones que se pasean alegremente por la humedad de las celdas, junto con un sinfín de murciélagos gigantescos, a los que se les atribuye el origen de una extraña rabia, convertida más tarde en pandemia, que parece marcar en la ficción lo que pocos meses más tarde ocurriría en la realidad con la expansión del COVID-19, atribuido en su origen a la ingesta de murciélagos en el mercado de Wuhan (Camacho Delgado, 2019). ${ }^{2}$

Es en el contexto de una pandemia global en el que Paz Soldán escribe su novela Allá afuera hay monstruos, ${ }^{3}$ concebida a modo de dietario narrativo - «Escribe, recuerda, que quede constancia» le dice la madre a la narradora (95)-, para dar buena cuenta de los estragos provocados por el coronavirus en todos los niveles de la sociedad, lo que se traduce en una obra descarnada y directa, que retrata y sincroniza las calamidades sufridas por la población en cualquier rincón del planeta, apuntando situaciones de un dramatismo afilado y muy agudo en todo lo que tiene que ver con la sanidad, la economía, la

${ }^{1}$ Barcelona, Malpaso Ediciones, 2017. En adelante cito por esta edición. Este artículo está enmarcado en el Proyecto Internacional RISE-TRANS.ARCH (Archives in Transition: Collective Memories and Subaltern Uses. ID: 872299, Programme: H2020, DG/Agency: REA) del Consorcio de Universidades europeas (Proyecto: RISE- TRANS.ARCH PIC: 999862518) de la Unión Europea.

${ }^{2}$ De la avalancha de libros sobre los orígenes de la pandemia, resulta absolutamente recomendable el Diario de Wuhan. Sesenta días desde una ciudad en cuarentena (Barcelona, Seix Barral, 2020), de la escritora china Fang Fang, prologado por Antonio Muñoz Molina.

${ }^{3}$ Chile, Los libros de la mujer rota, 2021. En adelante cito por esta edición en el propio texto. Agradezco al escritor Edmundo Paz Soldán el envío de la novela para poder llevar a cabo el presente trabajo. 
desprotección social, la alteración de los ritos de duelo, las relaciones interpersonales, las teorías conspiranoicas, el negacionismo, el mesianismo y la conciencia mítica, el cuestionamiento de la ciencia o la búsqueda desesperada de una vacuna para inmunizar a la población mundial. Con estos precedentes sacados de la vida cotidiana, la novela presenta una estructura tripartita y una división en pequeños capítulos o secuencias -en total son 56- donde se va dando cuenta, a través de la mirada de una joven narradora, de las situaciones y personajes que tienen que ver con ella y con su familia. Cada una de estas secuencias tiene un cierto grado de autonomía, como si fueran relatos de la pandemia, aunque cobran todo su sentido interpretativo en la hilación de acontecimientos que nos permite explorar la conciencia de la narradora en un mundo en continua crisis. Tal y como reconoce el autor en el epílogo de la obra, esta nació como un homenaje a uno de los grandes clásicos de la Revolución mexicana, cuya modernidad y actualidad parece más incuestionable que nunca:

La primera versión de Allá afuera hay monstruos la escribí entre abril y mayo del 2020; quería reescribir Cartucho (1931), libro de relatos de la mexicana Nellie Campobello que me deslumbró, y me interesaba dejar que en la historia se colara la realidad de esos meses (171).

Esto explicaría que hay lugares, personajes, situaciones, rasgos físicos o nombres que proceden del libro de Campobello y que han sido actualizados en la novela de Paz Soldán para representar la tensión política y revolucionaria que continuamente sacude al continente americano. Más allá de parecidos evidentes, lo cierto es que la estructura narrativa de la novela debe mucho a la red argumental de Cartucho, en donde se plantea, con una enorme agilidad narrativa, situaciones descarnadas que tienen que ver con una violencia implacable que crece bajo el paraguas de la Revolución. La velocidad que imprime Nellie Campobello a sus historias, así como el impacto de la violencia que transmite nos hace pensar, en este contexto bélico, en imágenes como «metralla argumental» o narraciones que se expanden como si fueran «bombas de racimo». En un contexto muy diferente, Cartucho ${ }^{4}$ y Allá afuera hay monstruos mantienen líneas de parentesco fácilmente rastreables, con una morfología muy parecida y todo tipo de guiños intertextuales por parte del boliviano hacia la gran narradora mexicana, como se percibe en la cantidad de relatos que componen la novela. ${ }^{5}$

Allá afuera hay monstruos plantea una doble línea argumental. Por un lado presenta la lucha médica y científica contra el virus, al que la narradora siempre llama «el bicho», los turnos inacabables de los sanitarios, la carencia absoluta de materiales apropiados en los centros de salud, la escasez de equipamientos, la incertidumbre sobre los síntomas de los enfermos, la llegada de nuevas cepas del virus, el reguero de cadáveres por todas partes, la escasez de morgues, la incapacidad de las funerarias para enterrar a

\footnotetext{
${ }^{4}$ Cartucho. Relatos de la lucha en el Norte de México, Madrid, Cátedra, 2019. En adelante cito en el propio texto por esta edición.

${ }^{5}$ Se cuentan de forma breve numerosas tramas que funcionan como chispazos narrativos, entre los que destacan por su autonomía narrativa las historias de Cruz (secuencia 1), Kily (secuencia 3), Rafaela (secuencia 8), Nati (secuencia 13), Juan Salahuez (secuencia 17), Beba (secuencia 18), hermanos Zampano (secuencia 19), Pepe díaz (secuencia 20), Rueda (secuencia 22), Lorena Castedo (secuencia 23), Don Guido y la familia González (secuencia 25), Reynaldo (secuencia 27), Pablo Limachi (secuencia 29), Salustiano Rodríguez (secuencia 31), Guillermina Baca y Kai Yucra (secuencia 33), Valentina (secuencia 34), Vladimir Tipman (secuencia 35), Martina López (secuencia 38), Dante (secuencia 39), Doña Julia (secuencia 43) y Abelarda (secuencia 52).
} 
los muertos, los aplausos de los ciudadanos al caer la tarde, la insolidaridad con médicos y enfermeros por parte de ciudadanos asustados, que ven en ellos una amenaza para el vecindario, y todo ello tiene como epicentro narrativo el hospital Madre de Dios, en donde trabaja como enfermera la madre de la narradora. Por otro lado, tenemos la lucha política, la violencia derivada de la gestión gubernamental y la banalización del problema sanitario a favor de la buena salud de la economía del país, lo que ha provocado el levantamiento de numerosos grupos armados, rebeldes a la política oficial, que aparecen unidos bajo la dirección de la líder popular Elsa Acosta, ${ }^{6}$ en lo que parece una variante pandémica y distópica de las guerrillas latinoamericanas de los años sesenta y setenta. El territorio que ha elegido Paz Soldán se llama La Estrella, quizás en recuerdo de la diosa pagana que rige los destinos de los personajes en Los días de la peste, y este, como enclave, reúne características propias de los espacios míticos, configurándose en parte como un locus horribilis, tan característico de una concepción estética que va de la literatura gótica decimonónica a los territorios infames de la literatura distópica.

En La Estrella viven la narradora, la mamá y su hermano Vicente, más pequeño que ella y afectado por algún tipo de patología psiquiátrica que lo lleva a estados de violencia y delirio que parecen estar en perfecta correspondencia con lo que ocurre afuera de la casa. Se trata de una familia disfuncional, en la que el padre, un negociante de todo tipo de baratijas y cachivaches, se ha quedado con el hijo mayor, llamado Dante, al que apodan el «mudito» por sus continuos silencios, ${ }^{7}$ en lo que parece un guiño intertextual a los infiernos de la Divina Comedia. La familia vive en un barrio popular, desde cuyo balcón la niña contempla el puente, que parece coronar «un río maloliente y enfangado de desperdicios» (p. 21). Tanto el puente como el río parecen limitar y perimetrar los contornos del mundo de la narradora, aunque hay otros espacios anunciados en la novela, como el hospital Madre de Dios, la localidad de Nieves, donde viven los tíos y el monte/bosque donde se da otro tipo de enfrentamientos entre las comunidades indígenas y campesinas y los madereros que aprovechan el caos social provocado por la pandemia para eliminar a todo tipo de líderes sociales incómodos de la zona y aniquilar a cientos de indígenas con el objetivo de controlar la comercialización de la madera, en lo que parece una nueva versión de La vorágine de José Eustasio Rivera. En esa zona llena de árboles, plantas y animales exóticos, vive un extraño chamán, llamado Tomichá, un ciudadano con formación universitaria que ha renunciado a las comodidades de la vida urbana y ha abrazado una suerte de filosofía naturalista que le lleva a defender por medio de un sistema de podcasts la convivencia necesaria con «el bicho», como una forma de recuperar la armonía con el cosmos.

\section{LA VIOLENCIA PANDÉMICA}

Por razones de composición literaria, la mayor parte de la información referida a la pandemia pasa por el protagonismo de la madre, quien trabaja como enfermera en Madre de Dios, un hospital de la zona relativamente bien equipado hasta la explosión del virus, en donde los sanitarios mantienen un fuerte compromiso con los enfermos y con la sociedad, reivindicando mejoras que van más allá del ámbito médico. Este motivo central

${ }^{6}$ Es muy posible que este personaje esté inspirado en Elías Acosta, el protagonista de «Elías» (Cartucho: 161-162) y «Las mujeres del Norte» (pp. 290-292); también aparece en «Agustín García» (pp. 169-170) y en «Ismael Máynez y Martín López» (pp. 293-296).

${ }^{7}$ En el relato titulado «Villa», con que se cierra Cartucho, aparece la madre de la narradora junto a su «hermano el mudo» (p. 297). 
de la ficción tiene su origen en el relato «Los heridos de Pancho Villa», en donde la figura materna tiene un papel central en el texto de Nellie Campobello, asumiendo el incómodo papel de tratar de curar a los combatientes heridos, cualquiera que sea el bando al que pertenecen. De hecho, en la ficción de Paz Soldán la madre desarrolla una intensa labor reivindicativa en el hospital, siendo una de las caras visibles del «sindicato de trabajadores de salud»y, como ocurre en el relato de Nellie Campobello, es acusada de colaborar con los enemigos del gobierno. A través de sus comentarios y de su conciencia asistimos a las actitudes frívolas y temerarias del presidente de la nación, quien antepone siempre los intereses económicos a la necesidad sanitaria:

Mamá se infectó los primeros días y sobrevivió; su inmunidad le daba ventaja sobre los demás. Yo le decía que tenía superpoderes y ella reía. Igual se revisaba seguido, no se sabía cuánto duraría la inmunidad ni si aparecería una nueva cepa. Incluso después de dar negativo algunos síntomas persistían: alucinaciones, piernas hinchadas y un dolor punzante en el corazón, como si estuviera a punto de explotar. La casa la dividió en dos: ella vivía en una salita del primer piso al lado de la cocina, que llamaba «el país de los enfermos», Vicente y yo en el segundo piso, en «el país de los sanos». Los gatos paseaban por toda la casa y, si bien algunos animales se infectaban, mamá había decidido que Ónix y Zircón serían libres.

En el hospital quedaban solo siete enfermeras, las demás estaban muertas, encuarentenadas o se habían dado de baja; un grupo de voluntarios de otras partes del país se esforzaba por llenar los huecos. Era inútil: varios cuartos, salas y un pabellón entero estaban abandonados, se los desinfectaba seguido y aun así el personal seguía cayendo.

Mamá odiaba al presidente porque no cumplió con sus promesas de trajes protectores, pruebas para los infectados y cuarentenas obligatorias. Su única obsesión fue reabrir la economía y lo hizo cuando el bicho todavía no estaba controlado; al poco tiempo había muertos apilados en las calles. Mamá aplaudió cuando se levantó la policía antidisturbios y se sublevó Acosta, Carrasco perdió el control de La Estrella y la ciudad pasó a manos de la líder rebelde (16-17).

Como hemos visto en la realidad de la pandemia, en cualquier rincón del planeta, la madre vive en sus propias carnes las mutaciones y variaciones éticas y morales de los entornos sociales, que pasan de considerar a los sanitarios como parte de un elenco heroico, a convertirse en una clase apestada, a la que hay que confinar y marginar en los nuevos leprosarios de la ciudad enferma.

Como resulta evidente en su anterior novela, Los días de la peste, Paz Soldán ha seguido muy de cerca todo lo concerniente a la tipología discursiva de la llamada literatura pestífera. El antecedente histórico más lejano lo encontramos en la llamada peste de Atenas (S. V. a. C.), que arrasó no sólo la ciudad griega, sino también amplias zonas de Etiopía, Egipto y Libia, tal y como fue descrita por el historiador griego Tucídides bajo el título de Historia de la guerra del Peloponeso. Fue Tucídides quien consolidó el motivo literario de la peste (Alsina, 1987; Ramírez de Verger, 1985), al tiempo que incidía en los efectos demoledores que la pandemia provocaba sobre la moral y costumbres de la población ateniense, consolidando un modelo arquetípico en el que la corrupción y la descomposición de los cuerpos lleva aparejada la degradación de las almas de sus ciudadanos, como una enfermedad irreversible del cuerpo social (Sontag, 1996). ${ }^{8}$

${ }^{8}$ Entre los muchos textos de Tucídides sobre la inmoralidad y la insolidaridad social quisiera destacar el siguiente: 
No solo son los sanitarios quienes van a ser considerados como agentes peligrosos para la sanidad pública, sino también todo aquello que sirve como instrumento o medio de atención a los pacientes, ya sean ambulancias («carrozas fúnebres disfrazadas de blanco», p. 51), helicópteros o la propia ropa que los identifica en cualquier espacio urbano, más allá del perímetro del hospital:

Mamá fue muy querida en los primeros días del bicho, cuando no se sabía qué ocurría y los doctores y enfermeras crecieron a los ojos de la ciudad. Luego aprendimos que el bicho era movedizo y saltaba fácilmente de un humano a otro, dinamitando sus entrañas o comiéndose su cerebro. Así cayeron muchos doctores y enfermeras. Un día a una doctora no la dejaron entrar a su edificio por miedo a que estuviese infectada, en otra ocasión incendiaron una posta sanitaria y la gente del barrio hizo una barricada para que las ambulancias no ingresaran con pacientes. También impidieron que una avioneta aterrizara en un pueblito porque, según los pobladores, traía pasajeros enfermos. A mamá la insultaron en la calle al verla con su uniforme de enfermera, a partir de ese día solo se cambiaba al llegar al Madre de Dios. Le preguntaba si no le dolía tanto sacrificio no recompensado y me decía que pensar así era de gente pequeña (23).

De hecho, la madre es de las primeras en contraer la extraña enfermedad (secuencia 12). Tras su regreso después de haber estado ingresada por culpa del «bicho», se encuentra pintada en la puerta de la casa el siguiente grafiti: «RATA APESTOSA» (47). La insolidaridad pronto muta en intolerancia y en violencia verbal cuando escriben en su pared: «Somos sus vecinos de la cuadra. Hay gente con asma y con diabetes. Por consideración debe irse a vivir a otra parte hasta que pase la crisis. Sea solidaria» (71). Tampoco los hijos de los sanitarios parecen correr mejor suerte. Cuando la narradora y su hermano entran en un supermercado, es el encargado del mismo quien los amenaza, porque sabe que su madre es enfermera y ha estado contagiada. En este establecimiento comercial hay, además, todo tipo de animales exóticos, raros, especímenes insólitos, más propios de coleccionistas que aptos para el consumo humano, en referencia al mercado de Wuhan, donde supuestamente comenzó todo:

Vicente y yo hicimos fila para entrar a hacer las compras en el mercado y pese al barbijo nos reconocieron. El encargado de seguridad nos siguió por los pasillos para decirnos «quizás mejor si no vienen, si el bicho se le pegó a su mamá también se les pegará a ustedes». Ojalá te toque el bicho y te mueras, lo pensé pero no se lo dije. Le respondí que estaba orgullosa de mamá y estudiaría para ser doctora, que algún día a él o a uno de sus hijos les tocaría estar bajo mi bisturí así que mejor se cuidaba.

También en otros aspectos la epidemia acarreó a la ciudad una mayor inmoralidad. La gente se atrevía más fácilmente a acciones con las que antes se complacía ocultamente, puesto que veían el rápido giro de los cambios de fortuna de quienes eran ricos y morían súbitamente, y de quienes antes no poseían nada y de repente se hacían con los bienes de aquellos [...] Ningún temor de los dioses ni ley humana los detenía; de una parte juzgaban que daba lo mismo honrar o no honrar a los dioses, dado que veían que todo el mundo moría igualmente, y, en cuanto a sus culpas, nadie esperaba vivir hasta el momento de celebrarse el juicio y recibir su merecido; pendía sobre sus cabezas una condena mucho más grave que ya había sido pronunciada, y antes de que les cayera encima era natural que disfrutaran un poco de la vida (Tucídides, 1990: 476-477).

Por su parte, Daniel Defoe recogió en su Diario del año de la peste, la degradación moral de la gente y «la corrupción de la naturaleza humana, la cual no puede tolerar el verse a sí misma en una situación más desgraciada que la de otros seres de su misma especie, y abriga una suerte de deseo inconsciente de que todos los hombres sean tan felices o estén en la misma situación desgraciada que ellos» (1969: 182). 
Un sector estaba cerrado, los pasillos bloqueados con turriles. Allí vendían los animales silvestres para la alimentación y los en vías de extinción para coleccionistas: una vez entré por equivocación y vi tortugas enumeradas con tiza en su caparazón, iguanas albinas, jaulas con parabas de frente roja. Según los rumores, en un sector similar de otro mercado se inició la infección; habían hecho desalojar las casas a dos cuadras a la redonda y personal con equipos de protección lo custodiaba. Mi hermano se quedó mirando el pasillo bloqueado y dijo: «Suinos ${ }^{9}$ malosos». Le conté que el gobierno había decomisado a todos los suinos de los mercados y los estaban estudiando en los laboratorios (25).

El hospital Madre de Dios es, en teoría, un espacio neutral, aunque en la práctica, las tensiones políticas lo convierten continuamente en una extensión del campo de batalla entre las fuerzas gubernamentales de Carrasco, el presidente, y las tropas rebeldes, lideradas por Elsa Acosta. Son muchos los momentos en los que el hospital se ve amenazado por uno y otro frente, con episodios de asalto para llevarse a cierto tipo de pacientes (secuencias 9, 37 y 40, entre otras), aunque tenga como consecuencia el contagio de los militares que participan en el asalto, muchos de ellos negacionistas de la gravedad del virus y partícipes de lo que comienzan a llamar la «dictadura sanitaria» (38). La tensión económica multiplicada cada día por la falta de soluciones, el cierre de mercados y negocios, la propagación del virus entre los sectores más vulnerables de la sociedad, la falta de cobertura social, de ayudas gubernamentales, de apoyo de las instituciones a los más débiles acaban agravando aún más la situación de la pandemia. Incluso dentro del sector sanitario hay quienes están contra este cierre preventivo de la vida económica para evitar el contagio masivo. Uno de los empleados del hospital, llamado Maclovio, llega a mantener una postura coincidente con el gobierno, a pesar de los horrores a los que se enfrenta día a día en las unidades de cuidados intensivos. Como dice el personaje «Convivir con el bicho iba a ser duro, pero hoy ya nos hubiéramos acostumbrado y estaríamos bien económicamente. Ahora no tenemos ni lo uno ni lo otro, somos un pueblo fantasma por culpa de esta dictadura sanitaria» (38). Será, para su desgracia, uno de los infectados irreversibles en esta particular guerra contra el «bicho».

La saturación en el hospital Madre de Dios pronto tiene su correlato con la saturación de muertos, muchos de ellos tirados en la calle o en cualquier muladar improvisado, con agencias funerarias que no dan abasto, morgues colapsadas y cementerios locales que deben improvisarse para dar cabida a la ingente cantidad de defunciones que se producen día a día en cualquier lugar de la zona infectada, dentro y fuera del perímetro de La Estrella. Así ocurre en Nieves, territorio complementario en la ficción, que funciona como un homenaje a varios de los relatos de Cartucho: ${ }^{10}$

Si así estaba la capital era peor en los pueblitos. En Nieves habían construido un cementerio solo para víctimas del bicho - ciento cincuenta enterrados ya, los reportes oficiales solo hablaban de cincuenta- en su hospital no tenían UTI ni pruebas para confirmar casos y les faltaban especialistas y medicamentos. Habían habilitado camas para pacientes en un hotel. La mitad de los médicos y una de cada cuatro enfermeras estaban contagiados, al igual que los conductores de las cinco ambulancias, tres de ellas manejadas por bomberos. El alcalde pidió que siguieran trabajando si no se sentían mal, aunque hubiesen dado positivo (142).

\footnotetext{
${ }^{9}$ Se trata de un tipo de cerdo (a veces semisalvaje) muy habitual en amplias zonas de Sudamérica.

${ }^{10}$ Así aparece en «El kirilíi», «El fusilado sin balas», «Desde una ventana», «Las tristezas de $E l$ Peet» y «Tomás Urbina».
} 
Son muchas las historias recreadas por Paz Soldán en las que aparecen escenas de una crudeza extrema, en consonancia con los horrores globales vividos en todas partes desde comienzos del 2020. Funerarias, policías, militares, sanitarios, personal civil o voluntarios que no consiguen recoger y enterrar a los muertos, generando una imaginería macabra tan impactante como anclada en la realidad inmediata. ${ }^{11}$ Así ocurre con los vecinos de la narradora, la familia González, cuyo abuelo, don Guido, tiene un final durísimo, con abandono del muerto ante la inminente descomposición y la consiguiente alteración de todos los ritos del duelo:

De pronto los González se encerraron en su casa y no se les vio más. En el barrio cundió el rumor: el abuelo estaba enfermo. Un día llegó una ambulancia, entraron los paramédicos y salieron con la camilla vacía: «Falsa alarma», dijeron.

Unas tardes después los González sacaron un cuerpo de su casa y lo cubrieron con una manta, lo apoyaron contra la pared junto a un letrero escrito con marcador negro: «HEMOS LLAMADO AL 110 Y NO HAY AYUDA». Subí al balcón, le prohibí a Vicente que lo hiciera. No podía dejar de ver el cuerpo tirado en la acera, me quedaba horas mirándolo. Al día siguiente alguien puso una sombrilla para cubrirlo del calor. ¿Quién estaría detrás de la manta? Un vecino me dijo que se trataba de don Guido. Mamá llamó a los Zampano para que lo recogieran, pero no había caso. Estuvo tirado tres días; se lo llevaron una tarde (80).

Un ángulo distinto y no menos interesante lo encontramos en el colapso que viven las agencias funerarias, como la «Nueva Vida», regentada por los hermanos Zampano, que no pueden mantener los protocolos necesarios de despedida, ni permitir el último adiós de los familiares y deudos, ni siquiera garantizar un lugar digno en algún cementerio o camposanto:

Cuando llegó el bicho las funerarias no dejaban de recibir llamados para recoger los cuerpos de casas y hospitales. Delfina, la menor de los tres hermanos, le contó a mamá que en una semana normal recibían dos llamados, pero esos días alcanzaban los treinta diarios. Iban a la casa o al edificio con la policía porque debían asegurar que las muertes habían sido por causas naturales. Al principio los policías entraban a las casas, pero luego de que varios se infectaron se quedaban afuera y Delfina debía mandarles fotos del cuerpo para que tomaran una decisión. Los hermanos ingresaban a la casa vestidos con equipos de protección y debían mover el cadáver a la camilla. La vez que se les cayó uno bien robusto, Delfina rompió un guante de látex al darle la vuelta. No se infectó por pura suerte. Los cuerpos se llevaban a la morgue o a una sala de refrigeración en la funeraria. Ésta tenía cabida para seis, pero llegaron a apilarse cuarenta y debieron habilitar la capilla y refrigerarla. Intentaron alquilar un tráiler enfriado para ponerlo a la puerta, pero era caro.

A Delfina le daba pena la partida sin ceremonia. Antes de la llegada del bicho le gustaba el trabajo de embalsamado, la oportunidad que se le daba a las familias de

${ }^{11}$ En la secuencia 20 tenemos un ejemplo estremecedor:

las funerarias y la policía estaban sobrepasadas, no les daba para recoger a todos. Una mujer debió convivir con el cadáver del esposo muerto por tres días, su sobrino llamó a los medios para quejarse y dijo que estaba botado «como un perro», que se pasaban la pelota entre el servicio de salud y la policía. Ni aun así fueron, por lo que tuvieron que sacarlo en una bolsa y prenderle fuego en la acera $[\ldots]$.

-Hoy tuvimos que embolsar siete cuerpos y dejarlos en el baño porque no había más espacio. Varios doctores no se han aparecido a trabajar, tampoco los encargados de la limpieza, todos nos están dejando (66). 
despedirse de sus seres queridos, ahora era imposible: debía llevarse el cuerpo de inmediato al crematorio o al cementerio. Cuando se habilitaron las fosas comunes fue peor (63-64).

Las calles se llenan de muertos arracimados, muchos de ellos calcinados, para evitar la nueva propagación del «bicho», al tiempo que se multiplican los doctores y las enfermeras contagiadas, personal sanitario en riesgo extremo, entre los que la narradora recrea los finales tremendos de Guillermina Baca, encargada de repartir los equipos de protección y de Kai Yucra, miembro del servicio de limpieza (secuencia 33). Estremecedora resulta la angustia de los sanitarios ante la difícil elección de aquellos pacientes idóneos para entubarlos y colocarles los escasos respiradores con que cuentan (secuencia 41) o los aplausos, originados en Italia, a favor de los sanitarios y propagados a lo largo y ancho de todo el planeta: «Todas las noches a las ocho la gente salía a los balcones a aplaudirlos» (p. 101). Tampoco faltan los curanderos, herbolarios y milagreros que creen haber encontrado la pócima adecuada para frenar la pandemia, con remedios inútiles, dada la gravedad e intensidad de la infección, ${ }^{12}$ siempre con el beneplácito del gobierno, que trata de ocultar y de maquillar las cifras de muertos, enredándolas en un laberinto aritmético de fallecidos por diabetes, hipertensión, obesidad y todo tipo de patologías crónicas, como una forma propagandística de intentar diluir el dramatismo de la situación, con sus piras funerarias, los enterramientos masivos sin apenas identificación personal, alterando así todos los ritos de despedida necesarios para sobrellevar el luto y rehacer la propia vida de los dolientes (Van Gennep, 1986: 158-177):

Es suficiente ver cómo crecen los cementerios, cuánto trabajan los crematorios. Esto es una crisis humanitaria, no le veo salida fácil. Recién van cuatro meses y yo con tantos muertos a cuestas. Eso sin contar los que han caído en la lucha. Se van sumando y el presidente no ha sido capaz de declarar un duelo nacional. No hemos tenido tiempo para honrarlos. ¿Lo tendremos o nos olvidaremos de ellos? Cuando son pocos es fácil recordarlos. Cuando se acumulan dejan de estar en tumbas con nombre y pasan al anonimato de la fosa común [...].

Algunos murieron carcomidos por el bicho sin darse cuenta, otros lo sabían y sufrieron: los pulmones colapsados y un corazón que ya no era suyo. No habían tenido una buena despedida, no fueron enterrados en campos con flores, música y un cortejo de dolientes, nadie les cruzó las manos o les puso brillo a sus caras. Los enterradores los bajaron sin mucho trámite, les tiraron tierra y escaparon como si hubiesen sido escupidos (153 y 155$)$.

\section{LA VIOLENCIA POLÍTICA Y MILITAR}

Desde las primeras secuencias narrativas se plantea el conflicto ideológico que una parte de la población tiene con respecto al presidente Carrasco, que parece encarnar muchos de los elementos populistas que se hicieron visibles en numerosos líderes internacionales desde el comienzo de la pandemia. Sin embargo, de todos ellos, quien

${ }^{12}$ Así lo encontramos en la secuencia 47: «los hospitales habían vuelto a ser sobrepasados, muchos morían en sus casas, otros probaban a curarse por su cuenta con vapores de eucalipto y otras medicinas tradicionales. Si alguno se salvaba era seguro que en las noticias hablarían de curas milagrosas por días. Un grupo evangélico suministró un medicamento veterinario a los vecinos de un barrio, con horribles efectos secundarios: diarrea y dolores de estómago» (p. 142). 
parece representar la encarnadura de Carrasco en buena parte de la novela es el presidente norteamericano Donald Trump, al punto de que se le describe como el «hombre anaranjado» (Paz Soldán, 2020), que manipula la información sin ningún tipo de escrúpulos y apela continuamente a la televisión para colocar sus mensajes positivos y pseudonegacionistas en una parte importante de la población. Carrasco maneja a su antojo no sólo los medios tradicionales y se enfrenta a cualquier periodista poco complaciente con sus mensajes, sino que también consigue llegar hasta los más jóvenes gracias al control de todo tipo de redes sociales y medios digitales. Su pretensión es siempre la misma, banalizar la gravedad de la pandemia mundial, que parece quedar relegada a un segundo plano frente a la importancia de la economía y las tensiones sociales originadas por el cierre de la actividad comercial. Llega a sostener, influido, quizás, por el presidente brasileño Jair Bolsonaro, que «Es una gripe más, el organismo nacional es fuerte y está acostumbrado a toda clase de bichos, a diferencia de otros países de organismos débiles», contribuyendo así a darle un toque mesiánico a su gobierno, como si el pueblo sobre el que gobierna fuera el elegido de Dios (Girard, 1995):

En la tele Carrasco hablaba de un país que no existía: «El enemigo invisible pronto será erradicado y haremos como que jamás existió», decía. Nunca pudo asumir que no tenía controlada la situación ni hizo caso a las recomendaciones de los científicos: su cara sin barbijo lo decía todo. Al dispararse los contagios no le quedó más que cerrar la economía, aunque se notaba su desinterés: un mes más tarde, acompañado de desesperados gerentes de empresas, reabrió un centro comercial con una pomposa ceremonia. El bicho no estaba vencido, se instaló con fuerza en el departamento y se extendió por amplias zonas del país. Nuestra región se rebeló [...].

«Nos irá bien porque somos un país elegido por la mano divina, impresionante cómo el Señor nos acompaña y cuida en nuestra historia, estamos orgullosos». Mamá cambiaba la tele si estaba el presidente porque prefería escuchar noticias de Elsa Acosta: buscaba el canal de la insurgencia y sonreía cuando aparecía su figura de líder. «Estamos en buenas manos», decía (31).

Toda opinión contraria a la política del ejecutivo es considerada no como una crítica legítima, sino como una conspiración para derribar al gobierno, al punto de que las cárceles muy pronto están atestadas de opositores, y el presidente potencia su lado mesiánico por medio de una batería nada desdeñable de recursos míticos y religiosos que le permiten llegar a sectores sociales -muchos de ellos rurales- que de otra forma serían inaccesibles, por medio de la manipulación litúrgica:

Veían golpe por todas partes, al principio exageraban y mentían, con esa excusa llenaban las cárceles con opositores al gobierno y eso era un problema: en las celdas hacinadas todos se infectaban. Era cierto que algunos merecían penas, como los que volaron las torres de comunicación porque decían que por ahí se transmitía la infección, ¿pero otros? Al jefe de una comunidad indígena del monte lo dejaron paralítico, solo pedía cajas de alimentos para su gente.

Carrasco no hacía caso a las críticas y ordenaba que los capellanes militares bendijeran la ciudad desde helicópteros que pasaban zumbando por nuestras cabezas, esos gestos le encantaban. Una vez sacaron a pasear, colgada de un arnés al helicóptero, una efigie del Tata Santiago, el santo del Ejército (56-57).

La actitud pseudonegacionista del presidente, su propensión a la manipulación informativa, su escoramiento hacia el pensamiento y las prácticas mágicas, el maquillaje permanente de los enfermos y fallecidos, la desatención del sistema de salud, el abandono 
de los ancianos en las residencias, no sólo recuerdan a la figura de Trump, sino también a Boris Johnson, en los primeros meses de la pandemia, y, sobre todo, a Bolsonaro, en connivencia permanente con los grandes ganaderos y las empresas madereras que están poniendo en grave riesgo el futuro de la Amazonía. Sin embargo, es Trump quien ofrece un arsenal de motivos, opiniones, tics políticos, gestos corporales y actitudes megalómanas más acordes con la trama argumental. Como ocurría con el mandatario neoyorquino, también Carrasco aparece continuamente con un comité médico, en donde más que apoyar sus tesis indefendibles, el jefe de los galenos - un trasunto del Dr. Anthony Fauci- parece contradecirlo siempre, poniendo en más de una ocasión en apuros al problemático presidente, quien reemplaza la información por propaganda y trata de equiparar en un mismo plano comunicativo el ámbito religioso con el conocimiento científico:

Las conferencias diarias del presidente al inicio de la crisis podían durar tres horas. Cuando el bicho avanzó hacia la capital se negó a declarar el confinamiento nacional y solo aceptó uno para nuestro departamento. En sus giras agitaba y agitaba un escapulario delante de sus seguidores, «el escudo protector de la fe es lo único que necesito», decía. Se llenaba la boca hablando de religión, pero no era capaz de mencionar un solo libro de la Biblia cuando le preguntaban por su favorito. Usaba modelos optimistas sobre la cantidad de muertes e insistía en que la economía debía mantenerse abierta pese a que algunos gobernadores, asustados ante los brotes en sus departamentos - en cárceles, hogares de ancianos y mataderos-, pedían restricciones de movimiento y ayuda con equipos de protección, pruebas y respiradores. «Es una gripe más, el organismo nacional es fuerte y está acostumbrado a toda clase de bichos, a diferencia de otros países de organismos débiles».

Las primeras semanas nos hizo creer que le importaba nuestra salud: aparecía con su comité de asesores, entre los que se distinguían un doctor famoso por luchar exitosamente contra bichos pasados y una doctora de bufandas elegantes. Era divertido verlos contradecir al presidente. Carrasco se cansó pronto, les pedía que se retractaran ante las cámaras cuando ellos le rogaban a la gente que usara barbijos o mantuviese la distancia. Comenzó él mismo a dar consejos médicos y dijo que nada creaba más anticuerpos para el bicho que el ayuno y la oración. Era un ser horrible, pero no podía dejar de verlo. Me atraía tanto como la violencia y la sangre, la muerte y la enfermedad. En el caso de Vicente era peor, él incluso lo admiraba.

Cuando apareció Elsa Acosta las conferencias de prensa continuaron, pero se convirtieron en publicidad para el gobierno. Los médicos se esfumaron y Carrasco se quedó solo ante las cámaras. Se peleaba con los periodistas que le hacían preguntas incómodas y pasaba en las pantallas de la sala de prensa propagandas que hablaban de lo bien que lo estaba haciendo (86-87).

El control y la manipulación informativa propician, incluso, la prohibición del consumo de sandías, la mayoría de ellas procedente de Santa Rosalía, ${ }^{13}$ lugar de origen de la líder rebelde Elsa Acosta, con el argumento peregrino de que quien come sandías está con los insurrectos, utilizando la comida como marca identitaria, como ya ocurriera en la España de los siglos de oro con el consumo de carne de cerdo para poner a prueba a los cristianos nuevos. Por otro lado, trata de presentarse ante su pueblo con una voz mesiánica, omnipresente en los medios de comunicación, portador de verdades absolutas,

${ }^{13}$ El motivo de las sandías de la localidad de Santa Rosalía está relacionado con los relatos «El ahorcado» (pp. 209-210) y «Las sandías» (p. 262) de Cartucho. 
un visionario pseudocientífico que busca remedios no en la ciencia, sino en el disparate conspiranoico y negacionista:

Potente, de conductor de programa televisivo. Seductora como la de un charlatán de feria. Así era la voz del presidente: hablaba con la convicción de un experto cuando era claro que improvisaba y decía lo que se le pasaba por la cabeza: «Entonces apuntamos al cuerpo, puede ser con un rayo ultravioleta y supongamos que somos capaces de meter esa luz dentro del cuerpo, a través de la piel o de otra manera. Interesante, ¿no? Dice la doctora que lo vamos a probar, ¿no, doctorita? Hay desinfectantes que hacen desaparecer el bicho en un minuto y la pregunta es si podemos hacer algo igual con ese desinfectante dentro del cuerpo. Una inyección, por ejemplo, una limpieza total de los pulmones y del corazón, sería interesante de verlo, hay que hacerlo con doctores, pero a mí me suena muy factible» (139).

La masacre perpetrada en un matadero presenta todos los indicios de que ha sido permitida -y hasta avalada- por el presidente Carrasco, con el consentimiento del alcalde y la gobernadora departamental, como castigo por las reivindicaciones de los trabajadores del ramo, utilizándolas como pretexto para eliminar cualquier foco de discrepancia $u$ oposición al gobierno:

Comenzaron los rumores: un grupo de trabajadores del matadero en el Mesón del Águila había aparecido con fiebre y otros llegaron a la UTI. Un dirigente dijo en la tele que no les habían dado barbijos y que en el matadero resultaba imposible mantener la distancia. El alcalde se puso del lado de los dueños y aseguró que los trabajadores no se estaban infectando allí sino en sus casas, porque les gustaba hacer todo aglomerados. Los dueños armaron un plan con el alcalde y la gobernadora sin consensuarlo con los trabajadores: quienes querían recibir su sueldo debían ir a trabajar al matadero y quedarse a dormir allí en turnos de cuatro semanas. Habilitaron un galpón con colchones, se les tomaba la temperatura tres veces al día y se los puso uno a dos metros del otro. Los baños seguían siendo compartidos y en el lugar donde trabajaban no había forma de evitarse.

Una mañana lo vi en la tele: el Mesón del Águila era un cerro ancho, chato y sucio en las afueras, con el aspecto de un animal echado en las patas delanteras y el hocico abierto. La periodista reportaba desde el matadero: un guardia tirado junto a una piedra grande, su boca entreabierta y los ojos cerrados. Un muerto alegre, pensé. Las chapas de la puerta de entrada rotas y cuerpos regados en el piso, algunos baleados, como si hubieran querido huir. Adentro, en todos los rincones, muertos y agonizantes: medio sentados, recostados en las puertas, las caras salpicadas de sangre con aspecto sorprendido. En otros casos la destrucción fue interna.

Algunos aseguraron que fueron cien los muertos, otros trescientos.

Después de lo ocurrido en el Mesón del Águila el presidente perdió apoyos; los militares y policías que lo defendían fueron vistos como enemigos. Elsa Acosta se convirtió en la esperanza de muchos (69-70).

Desde los primeros lances de la novela aparece planteado un conflicto con numerosas variantes entre el presidente Carrasco y la líder rebelde Elsa Acosta, en donde la política, los asuntos militares y la sanidad acaban conformando un cóctel explosivo, con implicaciones sociales dentro y fuera del ámbito familiar. De hecho, la propia división política está presente en el seno de la familia protagonista, con posiciones claramente enfrentadas. De un lado, tanto la narradora como su madre son simpatizantes de las fuerzas rebeldes, mientras que el hijo menor, Vicente, aquejado de alguna patología grave, el exmarido y el hijo mayor, Dante, son seguidores a ultranza del presidente, lo que permite a Paz Soldán explorar en el ámbito psicológico-familiar y en el sociológico 
las divisiones de una sociedad enmarcadas en el contexto de una pandemia global. La mayor parte de las discusiones que tienen lugar en la casa son a causa de las manipulaciones informativas que día a día protagoniza Carrasco a través de la televisión y las redes sociales, pasando por alto la gravedad de la situación sanitaria que certifica la madre-enfermera en su lucha incansable contra el «bicho». Esta situación la lleva a defender cada vez más los postulados y las ideas de Elsa Acosta, la rebelde, la Jefa, como la llaman, que aparece en muchos momentos de la narración con el halo mesiánico y de justicia con que vemos a Pancho Villa en los relatos de Cartucho.

Elsa Acosta, por su parte, tiene una historia trágica a sus espaldas, conectada con la criminalidad y los abusos perpetrados por los madereros de la región:

Acosta llevaba pantalones ajustados de tela negra y blusa vaquera, lucía pocos años en esos huesos forrados de piel morena. Sabía montar potros, enlazar bestias y hombres. Tomaba guarapo y se le conocían varias aventuras amorosas. Había nacido en Santa Rosalía treinta y cinco años atrás, en una casa al borde de la carretera. De niña vio la llegada de los madereros y cómo se preparaban para ingresar al monte; sus padres fueron activistas en contra un proyecto del gobierno que buscaba construir una carretera que lo atravesara. Al poco tiempo su padre fue asesinado en una protesta y ella decidió seguir ese camino. Cuando vio que el gobierno no estaba interesado en llegar a acuerdos ingresó a un grupo radical que atacaba a los madereros en defensa de las comunidades. Su madre le rezaba a la Señora, ella se la cuidaba (98).

Tanto ella como sus lugartenientes se presentan ante el pueblo con una aureola de misterio, de invisibilidad y cierto don de la ubicuidad, apuntalando así todos los elementos mesiánicos del personaje necesarios para su posterior mitificación, ya sea en un sentido positivo o negativo. De hecho, a través de Vicente, el hermano de la narradora, conocemos la leyenda según la cual «Acosta come murciélagos» (p. 92), en un momento en que se consideran a estos mamíferos placentarios como causantes de la pandemia mundial. Es tal el impacto que esta tiene en la familia, que la narradora, que ha querido ser doctora para homenajear a los sanitarios como su madre, a partir de cierto momento sólo quiere ser una líder como Elsa Acosta para luchar contra las injusticias sociales. Sin embargo, lejos del maniqueísmo propio de muchos relatos bélicos, en Allá afuera hay monstruos la crueldad del presidente tiene su correlato en la propia crueldad de Elsa Acosta, como así ocurre en el ajusticiamiento de Santos Ruiz (secuencia 26), inspirado en el relato «Los hombres de Urbina» (Cartucho, pp. 213-217) o en la actitud que mantiene frente a los norteños, colectivo demográfico que parece no encajar ni en la política gubernamental ni entre las fuerzas rebeldes ${ }^{14}$ y que van a convertirse en la comunidad más estigmatizada durante la pandemia. ${ }^{15} \mathrm{Ni}$ siquiera Elsa Acosta simpatiza

\footnotetext{
${ }^{14}$ En términos parecidos vemos la relación de Pancho Villa con los naturales del Valle de Pilar de Conchos (Chihuahua), conocidos como los concheños, en «Las lágrimas del general Villa» (Cartucho, pp. 267-268).

${ }^{15}$ Las tensiones políticas no sólo afectan a los seguidores del gobierno frente a los rebeldes, sino que tienen una dimensión más profunda, arraigada en la construcción de las repúblicas latinoamericanas desde los años posteriores a la independencia. En la novela encontramos una visión política enfrentada entre capitalinos y regionalistas, entre centralistas y norteños, entre urbanitas y las comunidades indígenas y campesinas, sin olvidar las tentaciones independentistas de algunos territorios, lo que remite a la desestructuración y a las tensiones internas de muchos de los pueblos americanos. En la secuencia 15 vemos las tensiones que provocan los norteños, que en muchos casos van a ser considerados chivos expiatorios de la pandemia:
} 
con los norteños, lo que supone un plus de vulnerabilidad para este colectivo rechazado desde todos los ángulos de la política.

Muchos de los relatos que tienen que ver con Elsa Acosta están claramente inspirados en los textos de Nellie Campobello, en donde el escritor Paz Soldán ha utilizado situaciones, nombres propios, motivos literarios, recursos retóricos o cierta atmósfera infantil que confiere un sesgo muy particular a la violencia (extrema) que articula la ficción. Valgan como ejemplos los relatos «La muerte de Felipe Ángeles», «La muleta de Pablo López», «Tomás Urbina», «Las águilas verdes», «Las tarjetas de Martín López», «Los heridos de Pancho Villa», «Mi hermano y su baraja», «Las balas de José», «Las sandías», «Las rayadas», «Las lágrimas del general Villa», «El sombrero», «Los dos Pablos», «Los oficiales de la Segunda del Rayo», «Las hojas verdes de Martín López», «Las mujeres del Norte», «Ismael Máynez y Martín López» y «Villa».

\section{LA VIOLENCIA ANCESTRAL Y TELÚRICA}

En una particular triangulación del poder se encuentra el personaje de Tomichá, ${ }^{16}$ una suerte de líder indígena y campesino, que procede del ámbito universitario y que en su concepción de la armonía cósmica cree haber encontrado las claves para convivir en paz con el «bicho» a través del respeto y el amor entre todos los seres vivos que integran el mundo natural, lo que trae a la memoria las obsesiones del personaje Rigo en Los días de la peste. ${ }^{17} \mathrm{Su}$ aparición al comienzo de la novela da pie para reflexionar sobre la

El desprecio creció contra los norteños que habían llegado hacía mucho a La Estrella. Eran gente humilde, que gracias a su entrega al trabajo se adueñó de las tiendas de abarrotes y los mercados. Uno de ellos estaba conectado con los primeros casos. Saquearon sus almacenes, incendiaron sus casas y los llamaron como los capitalinos nos llamaban a nosotros: sucios, atrasados, indios. Les escupieron en la calle y los despidieron de sus trabajos, incluso asesinaron a un joven que trabajaba en el mercado. Apareció con veinte balazos, se le desprendió una oreja y dijeron que su sangre era negra. Nadie quiso levantar su cadáver durante días. Un sintecho que se llevó la oreja - un pedacito de carne amoratada- apareció en una comisaría para devolverla, estaba asustado porque le habían dicho que si no la devolvía el bicho jamás se iría. fueron (54).

Algunos norteños cambiaron sus apellidos para no ser identificados como tales y otros se

${ }^{16}$ El nombre de este líder puede estar relacionado con el teólogo Roberto Tomichá, perteneciente al grupo de los chiquitanos, grupo indígena localizado en la zona oriental de Bolivia. Es director del Instituto de Misionología de la Universidad Católica de Bolivia, en Cochabamba, donde coordina programas de postgrado y ejerce como investigador de la historia y cultura de los pueblos indígenas americanos. Información procedente de $<$ https://www.capuchinoseditorial.org/autor/13627/tomicha,-roberto $>$.

${ }^{17}$ Como puede verse en la siguiente secuencia, referida al personaje de Rigo, su pensamiento conecta con el de Tomichá:

En Los Confines no fueron receptivos a la prédica. Tu religión es demasiado estricta, dijeron. No nos rendimos, y en plazas y calles la voz contó del hospital de aves. Nada permitía más felicidad que esas horas ayudando a que loros y tucanes superaran sus heridas provocadas por cazadores infames, accidentes y otros animales. La dedicación era a ellos porque ese era el llamado. Nuestra religión predicaba la palabra de la transfiguración de los hombres en animales y de los animales en insectos y de los insectos en hombres. El nuevo reino sería de insectos y pájaros y humanos en pie de igualdad, porque la primera ley de la Exégesis es clara: Todos los animales tienen la misma perfección.

Y la segunda: Lo admirable en los seres humanos es precisamente lo inhumano, aquello que los declara elementos del reino animal o vegetal. 
arbitrariedad del «bicho», que afecta de forma letal a ciertas zonas, mientras que otras permanecen indemnes, como si la enfermedad no existiera. La obsesión de Tomichá es «preservar la vida de los animales y las plantas e insistir en que la naturaleza tiene un valor más allá de lo útil» (20), presentándose en la novela como un iluminado, una suerte de chamán que conoce los arcanos de la naturaleza y sabe descodificar el lenguaje encriptado de plantas, animales, insectos y de todo aquello que conforma el espacio del hombre. Sin embargo, la madre de la narradora lo considera un «charlatán de feria», que vive en el seno de las comunidades indígenas, pero que se comunica con sus seguidores a través del podcast que periódicamente emite desde algún lugar, en una combinación desconcertante de mundo ancestral y esfera tecnológica. La información sobre el personaje la proporciona una amiga de la madre, quien ha sido testigo del modus operandi del extraño líder, cuya biografía y currículum lo sitúan en el texto como un gran manipulador, un intelectual tan brillante como apocalíptico en sus teorías, una suerte de chamán de formación universitaria que invita a sus fieles a ingresar en su particular secta para convivir con el virus:

Una amiga de mamá había estado en la comuna de Tomichá. Contó que dejarse infectar por el bicho era parte del ritual y quienes sobrevivían eran vistos como seres capaces de enfrentarse al desafío de un nuevo mundo en el que nosotros no éramos centrales. Estuvo un mes allí, convivió con ese hombre peludo que ganó todos los premios en el campo de la biología, pero que a los veintinueve años abandonó la universidad decepcionado de sus alumnos, incapaces de darse cuenta del cambio que se venía. Trabajó de cocinero en un hogar de ancianos, dejó de usar bancos y llevaba en los bolsillos fajos de dinero envueltos en ligas. Un día se fue a vivir al monte con una carpa y una bolsa de dormir. Poco después subió a la red Ecología para tiempos oscuros, un manifiesto de ochenta páginas que juntaba una investigación rigurosa sobre la destrucción de la naturaleza con pronunciamientos apocalípticos y profecía numerológica. Por ello se formó un culto en torno a él. Desconfiaba del Estado y aseguraba que solo una ciudadanía universal nos salvaría. Cuando llegó el bicho creó una comuna de doscientas personas en el monte y llamó a desobedecer la ley que prohibía reuniones de más de diez individuos. «No tenemos miedo al bicho», dijo, «aprenderemos a convivir con él: queremos al bicho ya». Las autoridades de La Estrella prohibieron a la gente que se acercara a la comuna bajo pena de cárcel, pero cuando reaccionaron era tarde; se habló de enviar militares a sacarlos y al final no se hizo nada.

La amiga de mamá decía que Tomichá tenía un sentido del humor cruel y era brillante.

Ella no pudo superar la muerte de tantos seguidores que entraban al monte a buscar intencionalmente al bicho y abandonó la comuna (20-21).

Por su particular manera de enfrentar la pandemia, Tomichá está más cerca de Carrasco que de Elsa Acosta. La invitación a vivir con naturalidad la amenaza vírica lo convierte en un aliado estratégico del presidente, no sólo por su influencia en las comunidades indígenas y campesinas, sino también por la penetración de sus ideas a través de las redes sociales y los nuevos soportes digitales. Su negativa a usar mascarillas,

El dios Mayor tenía cara de simio y pico de águila, cuerpo humano y ojos de mosca, así debíamos imaginarlo. No podíamos comer más que arroz y otras verduras a las que no se las hería cuando se las cosechaba. Debíamos caminar con sigilo, para no pisar arañas y hormigas, y no abrir mucho la boca, para no comer ningún bicho por accidente. Aprendíamos a disolver el yo en el nosotros, el yo era un pueblo y debíamos cuidarlo: billones de bacterias en la boca y la nariz y los intestinos y el pelo, cada una en su mundo y viviendo en simbiosis, ellas sí, con el nuestro (Los dias de la peste, p. 36. Las cursivas son del autor). 
a mantener distancias sociales, a utilizar todo tipo de medidas profilácticas para evitar el contagio acaba acercando las posiciones políticas del personaje a la voracidad capitalista del presidente (secuencia 26):

Tomichá dijo en su podcast que era bueno que el gobierno hubiera decidido convivir con el bicho. Entendía a los que pensaban que incluso esa medida les parecía poco y los invitó a unirse a su comuna (68).

En el imaginario popular llegan a creer que tiene poderes sobrenaturales (secuencia 26) y hay quienes sostienen que «Tomichá era un extraterrestre, que era el científico culpable de liberar al bicho como parte de un proceso de control de población a cargo de las siete familias dueñas del planeta y que en la comuna hubo un ritual de infección colectiva que terminó mal» (149). Teorías conspiranoicas y disparatadas que tienen su correlato en muchas de las noticias falsas que se han propagado como una segunda pandemia a través de las redes sociales y muchos medios de comunicación digitales desde enero de 2020 y que confirman la toxicidad que alcanzan ciertos discursos bien articulados en los que se combina de forma muy peligrosa la conciencia mítica con el pensamiento pseudocientífico, tal y como se verifica en sus intervenciones. ${ }^{18}$

Esta visión mágica de la realidad acaba convirtiéndose en una verdadera masacre para las comunidades que están bajo la influencia de Tomichá, según se desprende de los cementerios construidos en su zona de influencia para dar sepultura a un número ingente de víctimas del «bicho» (pp. 136 y 147), certificando así la inutilidad de los discursos filosóficos y visionarios ante la voracidad contagiosa del virus. Se le llega a conectar con el mundo de los murciélagos, en una referencia intertextual a Los días de la peste, en donde el origen de la pandemia parece estar ocasionado por el consumo de su carne, pero en esta ocasión Tomichá defiende de forma inequívoca el ecosistema donde viven estos mamíferos voladores, como una manera de apuntalar la armonía cósmica:

\footnotetext{
18 Así ocurre en la secuencia 39:
}

Tomichá emitió un comunicado en su podcast: «No entendemos al bicho porque no entendemos que ese no estar vivo y no estar muerto a la vez nos desafía. Habitamos su mundo y debemos hacer las paces con él para continuar, de nada sirve vivir de rodillas y con miedo. Las soluciones no están en el gobierno, ningún caudillo nos liberará si no rompemos nuestras ataduras interiores. Debemos adoptar una mirada planetaria porque con solo defender el departamento no llegaremos a nada, con solo tratar de entender el país no llegaremos a nada. Todos los órganos y tejidos de la tierra deben interpelarnos, no se debe destruir ninguna criatura del universo. Hubo un tiempo en que este bosque estaba lleno de otros animales y desaparecieron. Mientras estemos vivos no debemos dejar que nada ni nadie se extinga. Solo así la belleza volverá» (121).

Y lo mismo observamos en la secuencia 46:

El futuro se presenta con una extraña combinación de colapso continuado, que seguirá fragmentando la naturaleza y la cultura. Nos ofrecerá una nueva ola de soluciones de alta tecnología para controlarnos y pasaportes biológicos en un intento fracasado por prevenir lo inevitable, pero nada puede romper este ciclo a menos que haya un profundo reinicio de todo, como lo hemos visto tantas veces en la historia. El bicho nos debería llevar a un nivel más bajo de complejidad civilizatoria. La tormenta perfecta se prepara. Pierden su tiempo si tienen un gran plan para construir un mundo futuro basado en la ciencia y el argumento racional. Lo mismo si tratan de vivir en el pasado. Hay que ser sinceros sobre nuestro ínfimo lugar en el gran ciclo de la historia y sobre las cosas que podemos hacer y las que no (139-140). 
-Hay una leyenda que dice que viven en el subsuelo, en cuevas. Aprovecho para desmentirla: viven cerca de cuevas de murciélagos. Le dije a Tomichá que eso podía alterar el ecosistema y respondió que nadie lo cuidaba mejor que él (147).

El silencio definitivo de Tomichá, la ausencia de sus habituales podcasts, mensajes y discursos en los medios digitales hace pensar en un final trágico para el personaje, víctima de su propia estrategia de banalización de la enfermedad, pero como ocurre con otros personajes con una fuerte pulsión mítica, como Mackandal en El reino de este mundo, de Alejo Carpentier (Camacho Delgado, 2006: 57-70), o Ximenus en La mara (Camacho Delgado, 2016), de Rafael Ramírez Heredia, también Tomichá es capaz de vivir las más sorprendentes metamorfosis que lo devuelven al ámbito natural:

Las tropas de Carrasco pasaron cerca de la comuna de Tomichá, el canal informó que hubo muertos y heridos cuando quisieron negarles el paso; el gobierno desmintió esa noticia. Igual se rumoreaba en la ciudad que Tomichá había sido arrestado, aunque pronto cobró fuerza otra historia: en el momento en que lo iban a atrapar se convirtió en hormiga y se perdió por un túnel rumbo a su escondite en el centro de la tierra (103-104).

Paz Soldán aprovecha los vínculos de Tomichá con el mundo natural para introducir, de una manera sesgada, la denuncia contra las multinacionales de la madera y de otras materias primas que son esquilmadas de sus entornos biológicos, al tiempo que se ejerce una violencia indiscriminada contra la población autóctona y muy especialmente contra sus líderes y representantes, como viene ocurriendo, desde hace años, en países como Colombia, México, Ecuador o Bolivia. Ya en los primeros lances de la novela, la narradora se hace eco de todo tipo de leyendas que circulan en el monte y que, como le aclara una de las guardianas del puente, Rafaela, son relatos difundidos a modo de coraza protectora ante la voracidad de los madereros (secuencia 8). Nos interesa la historia de Beba, miembro de una de estas comunidades, quien sobrevive en la calle vendiendo dulces, después de haber sido despedida de una fábrica de zapatos por culpa de la pandemia. Su testimonio resulta fundamental: «-He visto a mi gente luchar contra los madereros, pero ellos tenían perros y fusiles -se le hundían los ojos-. Yo no puedo porque estoy vieja» (61). Su testimonio es importante porque introduce un elemento fundamental en la historia más trágica de América Latina como es el tema de los desplazados, generalmente por la violencia, pero también por las catástrofes naturales, la presión del narcotráfico o por las políticas absolutamente tóxicas de las grandes multinacionales energéticas. En este caso, Beba pertenece a una comunidad masacrada por los madereros, quienes se han aprovechado de la impunidad que conlleva la pandemia, al tiempo que han provocado una enorme y fatal desforestación, que trae hasta la conciencia del lector las políticas ecocidas de Bolsonaro con respecto a la Amazonía brasileña:

Todos los días [Beba] me aseguraba que ya mismito se volvería al monte y yo me entristecía: su gente no tenía inmunidad con el bicho ni con ninguna enfermedad respiratoria. Los madereros y el bicho los diezmaban, por eso muchos se venían a la ciudad. Ella consiguió un trabajo mal pagado que le permitió alquilar un cuarto en un edificio cerca del estadio, pero poco después comenzó todo, hubo muertes y despidos en las fábricas $[\ldots]$.

Un soldado llegó con la historia: los madereros habían provocado una matanza en el monte, se aprovechaban del bicho para deforestar y expandían sus dominios 
amparados en leyes aprobadas por el presidente en plena crisis. El soldado dijo que no se le iban de los oídos los gritos de los quemados vivos (61-62). ${ }^{19}$

Siempre son los grupos más débiles los que sufren las consecuencias de una violencia multidireccional que se ceba con los pueblos indígenas y las comunidades campesinas. Así ocurre con la comunidad guaqui (situada a orillas del lago Titicaca), personalizada en la figura de Valentina, una curandera y huesera con fama de bruja, quien va a vivir en sus propias carnes los rigores de la pandemia y de la violencia institucional (secuencia 34), así como la extinción de su propio colectivo:

Mamá me contaría luego que se trataba de los indígenas de la comunidad de Valentina, el bicho había ingresado ahí porque de nada había servido la medicina tradicional, tampoco los remedios que las ONGs les habían hecho llegar. Cincuenta contagiados, quince muertos.

-Quizás sea el fin de su comunidad. Demasiados bichos en los últimos años, particularmente duros con ellos. Se ha pedido que en el certificado de defunción se anote que son indígenas para que se vea la desproporción y el gobierno tome medidas, pero al presidente no le interesa.

Algo similar debía estar ocurriendo en otras comunidades y en la comuna de Tomichá (130-131).

La realidad se funde con la ficción cuando Paz Soldán incluye en su novela la muerte del protagonista de la película El abrazo de la serpiente-El abrazo de las plantas en la novela-, Pablo Bolívar, víctima también del coronavirus y custodio en la realidad fílmica del secreto de una planta que cura todas las enfermedades y que es una variante amazónica del tópico cervantino del bálsamo de Fierabrás:

Una mañana la llamaron para contarle que acababa de fallecer en Roriazul Pablo Bolívar, el actor que representaba a Pablo Karamaka en El abrazo de las plantas, su serie favorita. No le habían hecho pruebas, pero por los síntomas era claro que el bicho se lo había llevado.

-Tan guapo -dijo-. Su cara dorada, su frente bien hecha, las espaldas anchas. A tu edad yo suspiraba por él. Es que no lo puedo creer, lo vi hace poco. Paraba fumando, decía lleno de risa que no iba a morir sin antes darle una chupada a su cigarro. Tenía todos los dientes de oro, ${ }^{20}$ dicen que los perdió por culpa de una bacteria. No quiso vivir en la ciudad, cuando se volvió famoso se quedó un tiempo en la capital, pero extrañaba su Roriazul, donde era un líder respetado.

Karamaka estaba inspirado en la vida de Bolívar, uno de los doscientos roriazules que quedaban. Un siglo atrás eran más de dos mil, la explotación del caucho los mató. En la serie Karamaka guiaba a exploradores extranjeros en busca de una planta con propiedades alucinógenas. «¿Dedicas tu vida a las plantas? Es de las cosas más razonables que le he oído decir a un blanco», mamá recordó emocionada esa frase. Otra: «El bosque va a desaparecer. Casi casi se está cumpliendo» (151-152).

A casi un siglo de la irrupción de metagéneros narrativos como la novela terrígena, la novela de la tierra o de la selva, estos guiños intertextuales de Paz Soldán en Allá afuera hay monstruos conectan con los grandes temas de la literatura hispanoamericana, como es el enfrentamiento del hombre con la naturaleza, ejemplificado en obras como $L a$ vorágine de José Eustasio Rivera o Doña Bárbara, de Rómulo Gallegos, o la

\footnotetext{
${ }^{19}$ Esta imagen espeluznante procede del relato «La sentencia de Babis» (Cartucho, pp. 195-196).

${ }^{20}$ Aparece en el relato «Los dos Pablos» (Cartucho, pp. 275-276).
} 
actualización, una vez más, del binomio civilización versus barbarie, apoyado ahora en la importancia de las ciencias y la investigación frente a la manipulación de los recursos mágicos y telúricos o el carácter prioritario del mercado, como motor de la vida social. Con Allá afuera hay monstruos el escritor Paz Soldán vuelve a dar muestras de su enorme talento literario, esta vez con una historia construida desde la experiencia más dolorosa e inmediata de la pandemia mundial y el confinamiento, poniendo en entredicho la falacia de los diferentes discursos que tratan de banalizar la virulencia de la enfermedad, al tiempo que sacralizan todo aquello que contribuye a ensalzar el promontorio de la economía capitalista.

\section{OBRAS CITADAS}

Alsina, José (1987), «¿Un modelo literario de la descripción de la peste de Atenas?», Emerita, LV, 1, pp. 1-13.

Bauman, Zygmunt (1999), La globalización. Consecuencias humanas, Ciudad de México, FCE. Benedictow, Ole J. (2011), La Peste Negra (1346-1353). La historia completa, Madrid, Ediciones Akal.

Camacho Delgado, José Manuel (2006), Comentarios filológicos sobre el realismo mágico, Madrid, Arco Libros.

Camacho Delgado, José Manuel (2007), «Sófocles, peregrino en Macondo. De los enigmas insolubles a las pestes literarias en la narrativa de García Márquez», Ínsula. Revista de letras y ciencias humanas, 723, pp. 21-24.

Camacho Delgado, José Manuel (2016), «El infierno sobre rieles. La violencia que no cesa en $L a$ Mara de Rafael Ramírez Heredia», Anuario de Estudios Americanos, LXXIII, 2, pp. 539572.

Camacho Delgado, José Manuel (2019), «Horrores globales. Religiosidad popular, mundo carcelario y pandemia en Los días de la peste de Edmundo Paz Soldán», en Eva Valero Juan y Oswaldo Estradas (eds.), Literatura y globalización. Latinoamérica en el nuevo milenio, Barcelona, Ántropos, pp. 141-152.

Defeoe, Daniel (1969), Diario del año de la peste, Barcelona, Seix Barral.

Dorfman, Ariel (1970), Imaginación y violencia en América, Santiago de Chile, Editorial Universitaria.

Fang, Fang (2020), Diario de Wuhan. Sesenta días desde una ciudad en cuarentena, Barcelona, Seix Barral.

Foucault, Michel (1979), Vigilar y castigar. Nacimiento de la prisión, Madrid, Siglo XXI.

Girard, René (1995), La violencia y lo sagrado, Barcelona, Anagrama.

Montoya Juárez, Jesús (2019), «La velocidad de los cuerpos: mercado, distopía y desecho en Los días de la peste, de Edmundo Paz Soldán», Co-herencia, XVI, 30, pp. 159-187.

Paz Soldán, Edmundo (2017), Los días de la peste, Barcelona, Malpaso Ediciones.

Paz Soldán, Edmundo (2020), «La pandemia exacerbó la peor forma del individualismo americano» (entrevista), La Tercera, 13/09/2020, $<$ https://www.latercera.com/culto/2020/09/13/edmundo-paz-soldan-la-pandemiaexacerbo-la-peor-forma-del-individualismo-americano/>.

Paz Soldán, Edmundo (2021), Allá afuera hay monstruos, Chile, Los libros de la mujer rota.

Ramírez de Verger, Antonio (1985), «La peste como motivo literario (a propósito de Coripo, Ioh. III, 338-379)», Cuadernos de Filología Clásica, 19, pp. 9-20.

Sontag, Susan (1996), La enfermedad y sus metáforas; y el sida y sus metáforas, Madrid, Taurus. Spinney, Laura (2018), El Jinete Pálido. 1918: La epidemia que cambió el mundo, Barcelona, Crítica. 
Pandemia y violencia política en Allá afuera hay monstruos, de Edmundo Paz Soldán

Tucídides (1990), Historia de la guerra del Peloponeso, Libros I-II (introd. Julio Calongo Ruiz y trad. Juan José Torres Esbarranch), Madrid, Gredos.

Van Gennep, Arnold (1986), Los ritos de paso de Arnold van Gennep, Madrid, Taurus.

Recibido: 08/09/2021

Aceptado: 10/10/2021 